
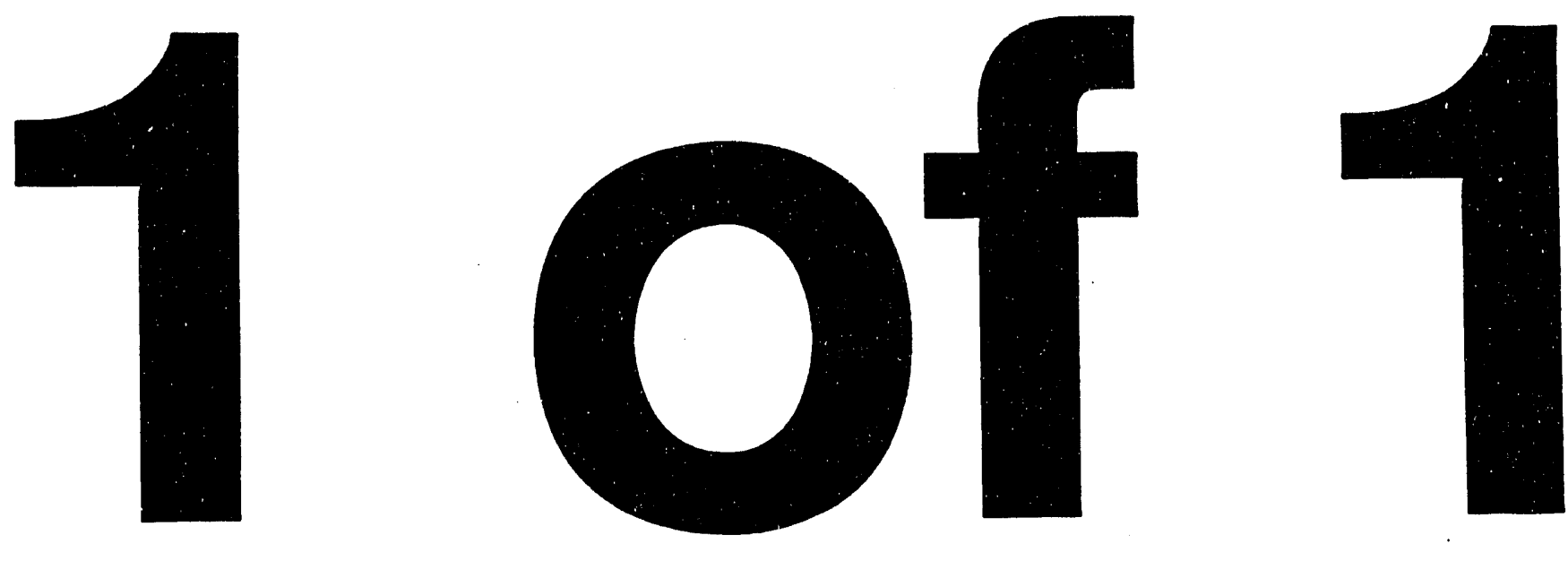


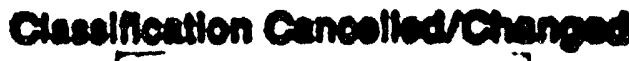

To UNGLASEIFIJO

By Authorty of D.

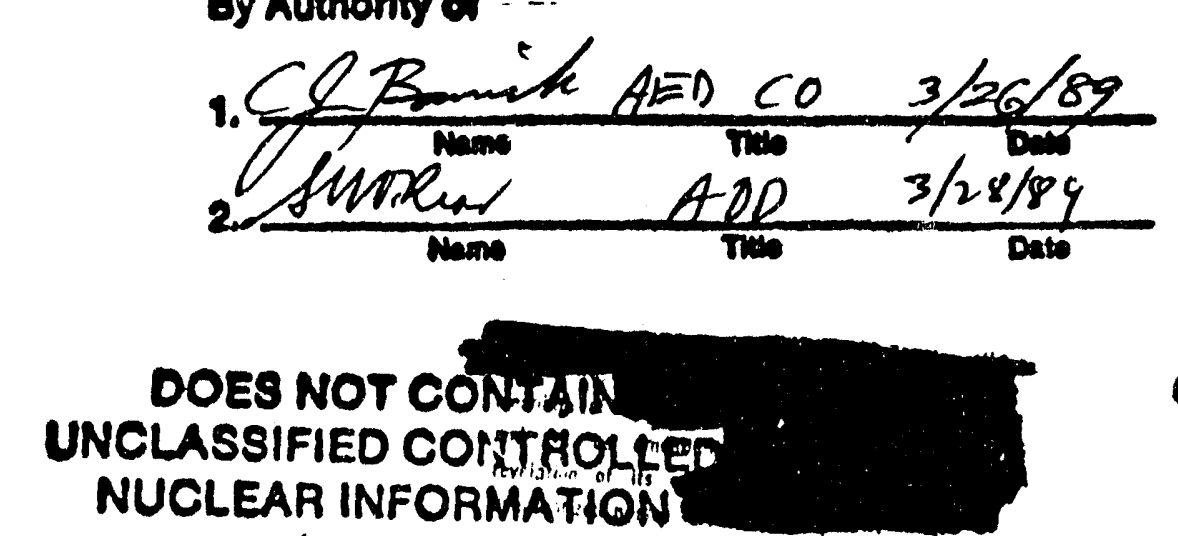

$\cos 41$ - $111 \cdot+1$

Copy 2 -............... Copies.

2 - $3110+2$

Qreaneralt

Givinem $5 R / H--75 \%$

2- III tre
Creven

rechosical

3. J. B. M1100

- R. A. Itans

5 - R. A. Drane

6. M. D. Mitaker

7 - H. D. Indtater

8 - Chronological

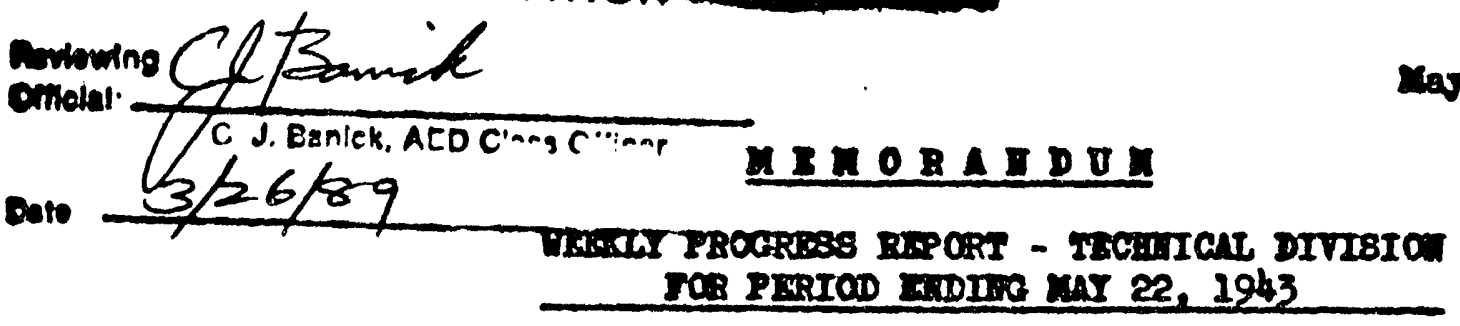

nav 26, 1943

200 and 300 Areas - Hood Narthington

\section{Dood Vorthington}

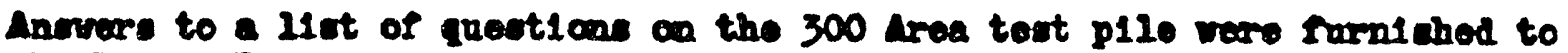
the Dosige DIVIa1ca. Their prollatinary abotches, based on these anvrare (efren rexballs on Ilas 8), rare taken to Chlcago and discused of th Compton,

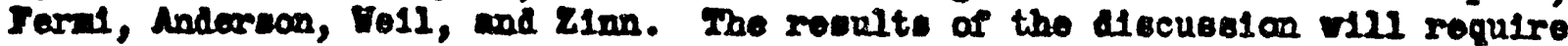
modification of the anvere, almoot entirely in the direction of ereater case of comotrretion.

During this vist, Eraphite opeciflcations and manufacture vare discussed vith Ill1son, Doen, Miles, Hanleter and Macpherson--the latter two fron Iatical Carbon. It appoar that there was bo difflculty in nooting tho required dolivary cobodule is loublo-flred erephite of 1.64 density rather

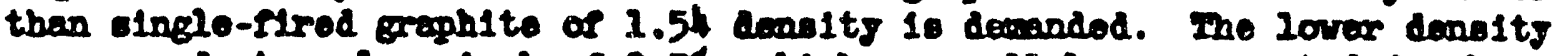
corresponds to a 1086 in $k$ of $0.3 \%$, vinteh was rell bo compenested for by ercater purity. Data on the phyalcal properties and chenical analjol of the 11ghter graphite will be obtained by Chicago oo that an Intelligent deciolon as to 1t. mitability ar be mado.

Inpuritios, eapocially ranadin, in the eraphito are responsiblo for a lose In $x$ on the order of 1.5\%. The menger orldence 18 that this is oufficlentiy varlable from bar to bar (though probabls not from carload to carload) so that separation by a piece-to-ploce functional test rould parndt bulldine a cubstantial increase in $k$ into the pile, in comparion with randou distribution of the oraphite. Doan vill atart an analrtical program on potroloum coke in an effort to uncover a meens of refucing $V$ by a cholce of rav material. Pitch should alco be investigated. 
Dood Darthinten - (cont'd).

Discherging by cropping was llocuesed with Ioverott no exprosed on opinion that if tho elnge rere dropped into 6 foot of rater to fall on wood, there rould be IIttlo or no demage to jackote. This olll be tested when I aluge arrito in Aulcago this wook. Ho bave enked that two alug 1.28 " in dianotix and approdimately $8^{\circ}$ Iong be roughly jackotod end tootod to holp

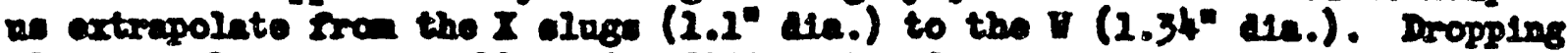
ulnge on alugs is a problen of a llfierent order.

Tho dipplacenent of afr by helim appeare wore favarbie in the 11ght of Chica 80 coperimente about to be reported. It appeare, hovever, that the redioactivity of the holim wa be not profoundy influenced by 1 to argon

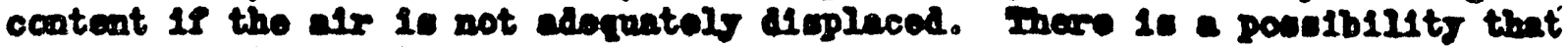
argon sccounts for the mexpected ralloactive ons that we found in the

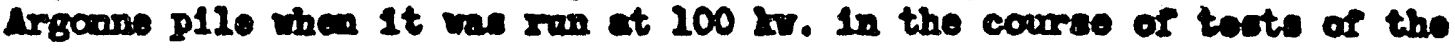
blological ahiell.

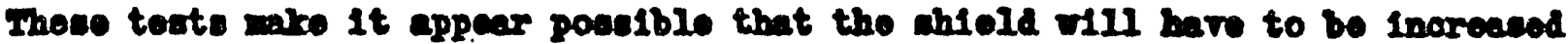
In thicknos unlese the epparent leakage of radioactivity alould prove to be cansed by the secenpe of radicactive eas.

I. A. Janes

Jeckots

On Iuosday and Iodnowdar this robjoct wes discresed in dotall with Chipmen, Creute and row at Cnlcago. Imree I1rm are now doing developesent vart on

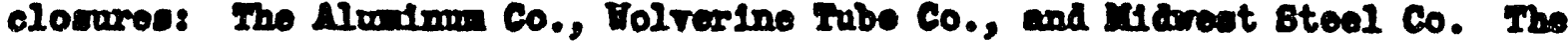

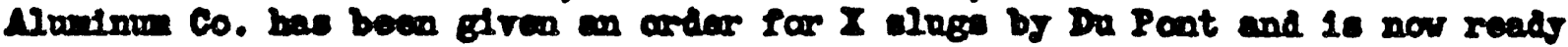
to begin the work. Derelopment work will contimue at the other two loceticen, bowever, eince IInge mas sequire a afferent clowre.

On Iridar a large group not at Iow Ieanington, Pa. to discuse IInal tolerances and procedure for the Nluninim Co.' work. The resulte olll be roparted ceparately after the revised printe hare been approved. The onls tro points roquiring further dovelopment in this progran are deganding and the 3000 hodrogen tert. For the timo bolng, I eluge will bo jacketed if thout deganaing and on accurate record lept. Those alnge rill 80 into the outer portice of the p110. Nfter further experineatal work hes lown the best procedure for degaesing, the rect of the $X$ eluge will be so treated.

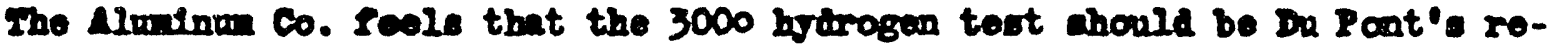

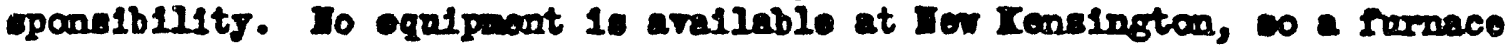
will bave to be procured in an case. There are obrlous advantages in ruming this tost on the plant site arter tranoportation and handing are coupleted.

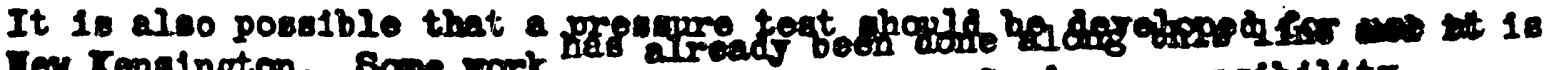

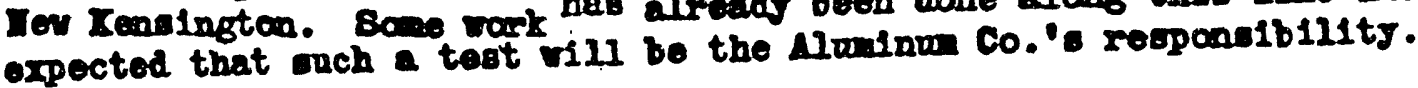


I. G. Joner (Cont'l.)

rabing

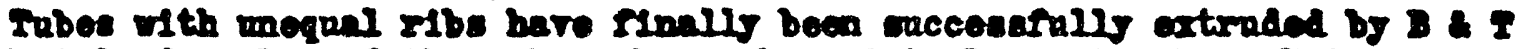
Motale Co. Ine of those here boen ahlppod to Dotrolt, were Bol verine Tabe Co. will atteupt to drax the to rinal alre.

\section{Machenges}

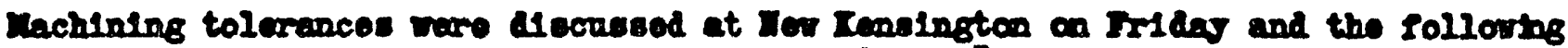

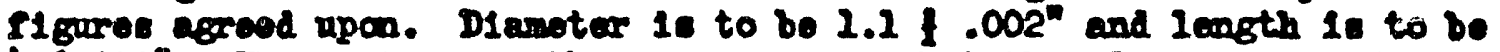
1.010". Ino contour of the upper correr that the alminum cap fits dorm into

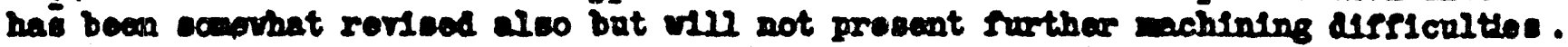
Ferring-iall-ramin 8aso Co. 1s now ready to otart machining and expectoto bulle up to a peat of 12 tons per vear nhartly.

\section{Baran 8teel}

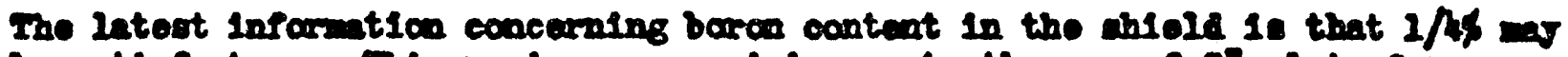
be catiafactory. Inle rovices our opinion as to the nes of 2 plate for

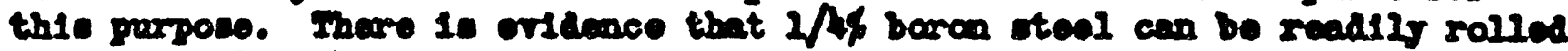
ueing nownel tochnigue.

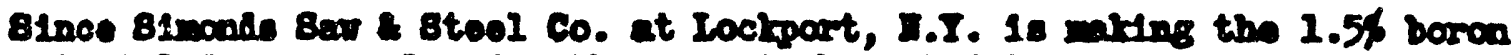

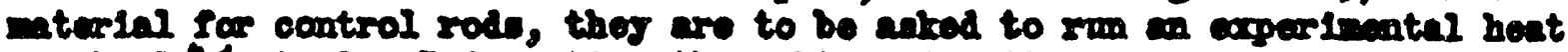

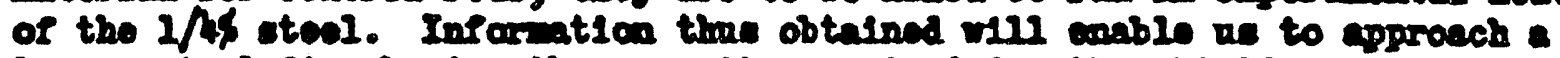
Inrger oteal firn baring the capacity required for the ablold naterial.

ramal

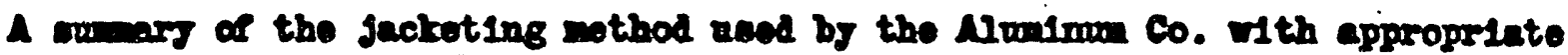

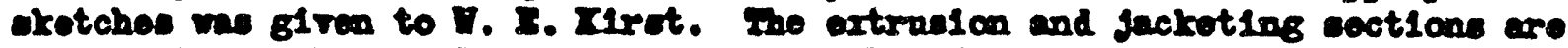
now conplote. It is plamed to rinlt the Dro Vorke aco tim in the now Iutwre, wo that a wown of the malting and casting procodure can be vritten for the ramal.

2. B. Drex

Agnin the rook ba largely bown doroted to rarlons problens acsociated of th our utud of nothode of so dictoributing the motal in the pile and the nor of

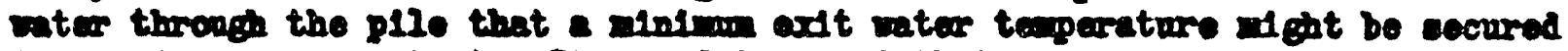

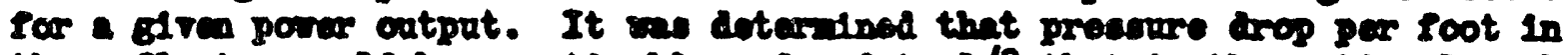
the reflector could bo practicably roduced to $1 / 8$ that in the actiro length

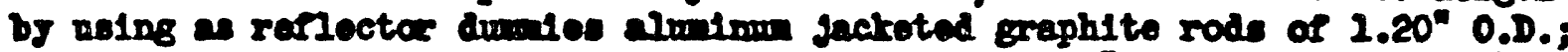

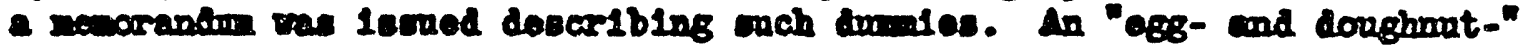

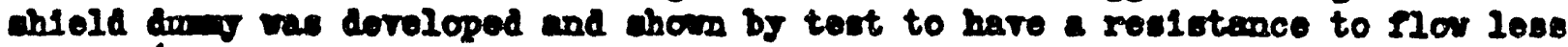
then $20 \%$ of that of an equal 2 magth of the 2.2 an. anmine about the active

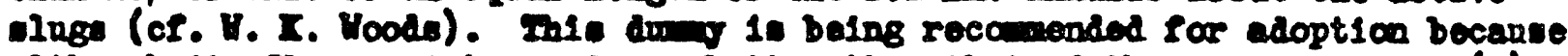
although its rlor realotance is no botter than that of the angere, it is (1) cesier to cont ifth alwimu, (2) has no posalbilits of roteting during oparatbn, and (3) is ostinated as boing onis $1 / 5$ as contly as the angers to wite. Cal-

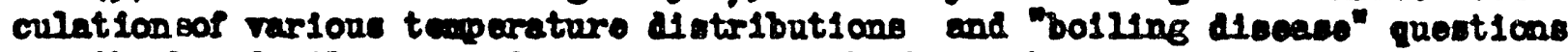
for the bowed p1le are woder vay. Innianily has taken over a pert of the bolling dicease calculation during Voods' absence on racetion. 


\section{B. $\operatorname{sen}\left(\cos \cos ^{\circ}\right)$}

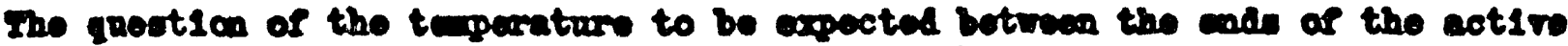

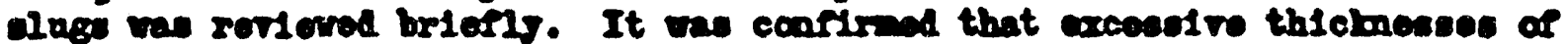
elmimn vould be nooded to rednce thl tepertature belor tho bolling point by IIn action of the alminm coating at the ands.

Work in prospect, other than as noted aboves

1. Btades of thermel trensient in the p1lo when the rater flos is Interrapted.

2. The Colubin River lilution problea.

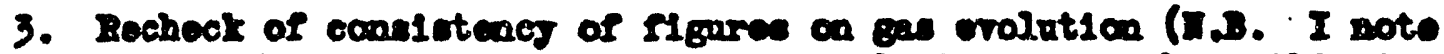
that $X$. Has 10 now voriding on on orolution, wo perbape this is unnocensary.

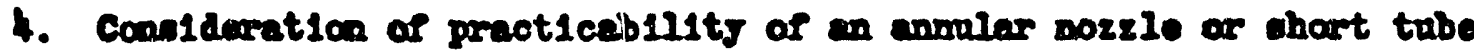
farmad by insouting a rod in a pipe.

\section{I. Hoode}

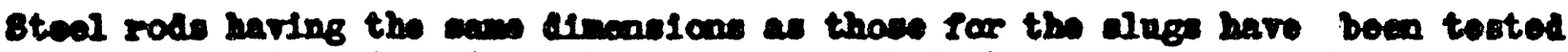
for preacuro trop in a 2-ft. 1costh of.3-ribbed alvoinm trbing and in a

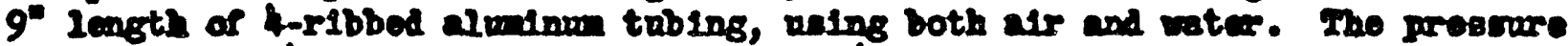
frop with the 4-ribbed trbing is unthin 105 of the calculated ralne; the

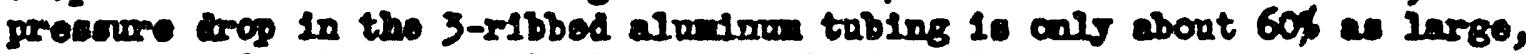

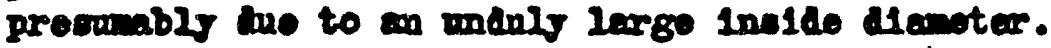

The prearure drop for varione durg alnge could not be accurataly obtalnod in

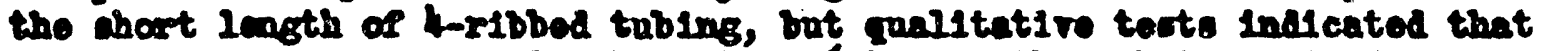
this proscure trop vas ond about 15-20, inger then that obtainod in the 3-rbbed trbing. Presure drops rith am olnge aro reported belor an a percentage of those obtained with ejlinirical aluge at a given 10 rete in

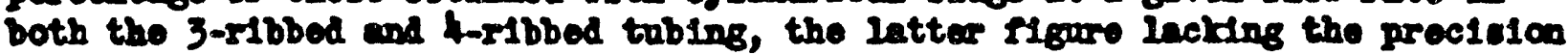
of the formor.

\begin{tabular}{|c|c|c|}
\hline 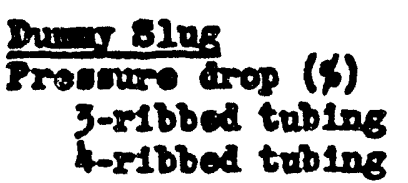 & $\begin{array}{c}\text { Bhip Auger } \\
29 \\
20\end{array}$ & $\begin{array}{c}\text { Iudet De111 } \\
15 \\
10\end{array}$ \\
\hline
\end{tabular}

Vith the ship auger, about $50 \%$ of the prosemro frop is dne to friction in the opiral ahemnel and the rest is we to lose in getting fren cre anger to the next around the contral "nubbing" wich corre as epacer rods. The corloumese of this latter effoct vas reduced by epproprelate romaling of the approaches to

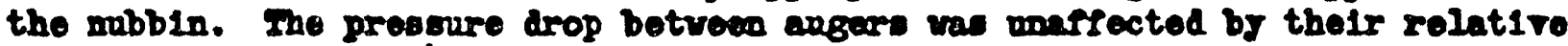
orientation. In the 4-ribbed trbing, the anger rotated at 110 rates of $3.1 \mathrm{lbs} . /$ cec. and greater, so $1 \mathrm{t}$ rowld be nocescary to chenge the direct10n of rotation half-ray through the elng in order to prevent opinning of the alug Insile of the tube vith consequent crosion. Buch a change in arrection has only ninor arfect on the preserve drop. 
D. E. Voode (cont'a.)

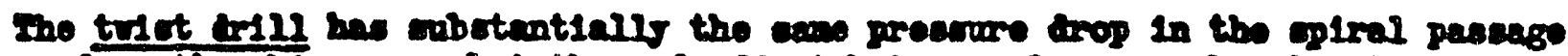

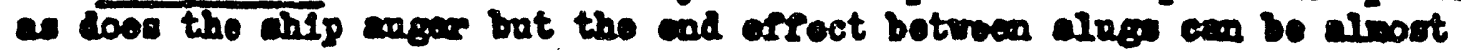

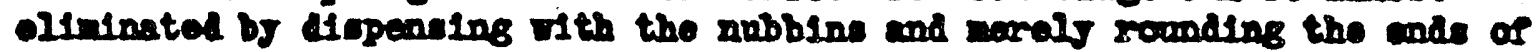

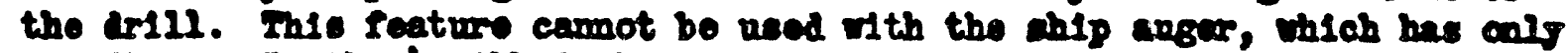
an Finte. In the 4-ribbed aluimen trbing, water sated in creese of

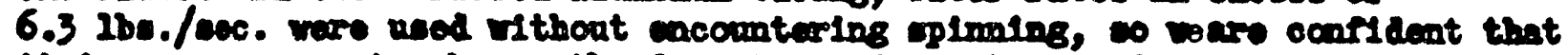

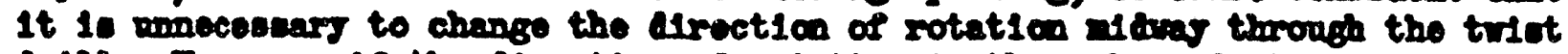
Arill. Forevor, is the diroction of rotation 10 them chenged, torts wert bo

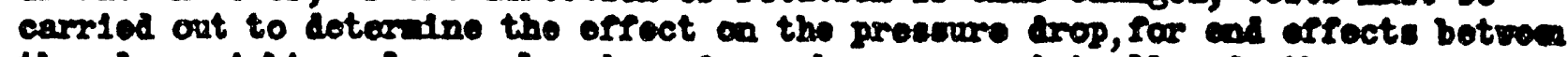
the eluge doft no langer bo minor in cuch a case. Netrally, further vors on

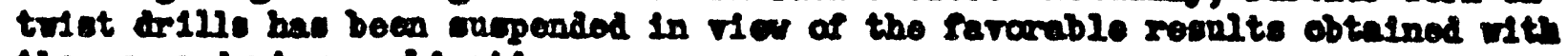
the ogs and ring comination.

Tho egs and Fing combination conalote of canalng the vater to Rlor alturatelf

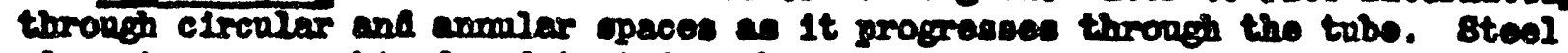

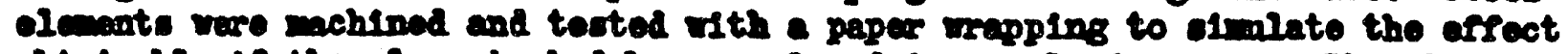

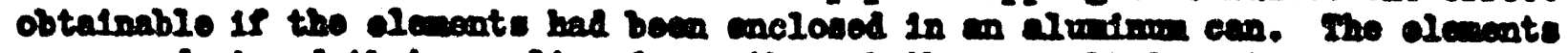

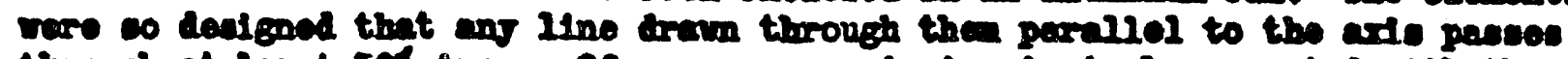

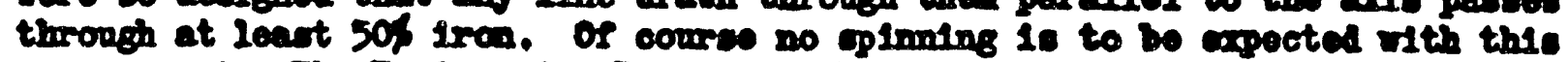

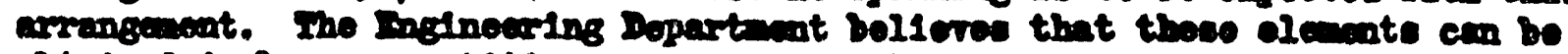

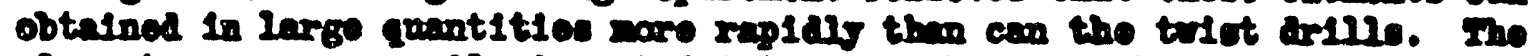

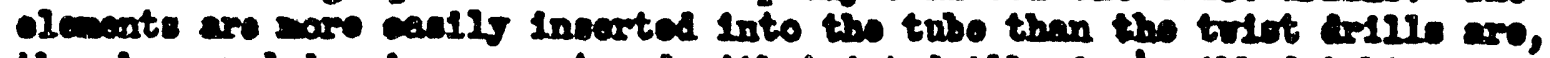

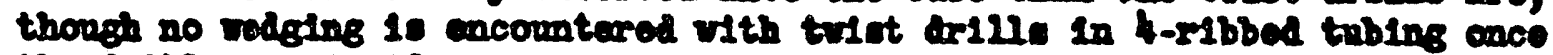
the dirlile are inc1de.

\section{Ionienily}

Inventigation were mal into the pounible tjpes of otorages far the pile area

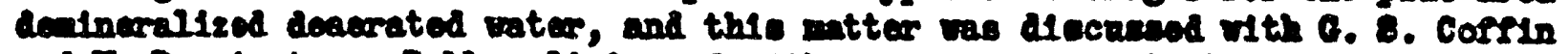
and $I$. Dunningtan. Iubber lining of either concrote or otoel tank world bo

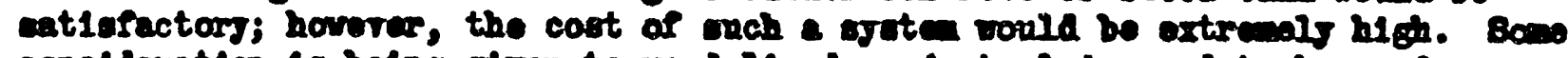
consideration 1s belng fiven to rood-1ined or Jut plate wood tanke, and com

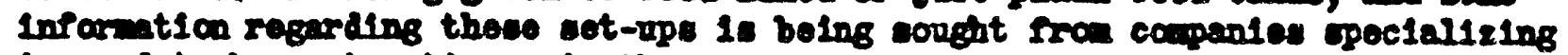

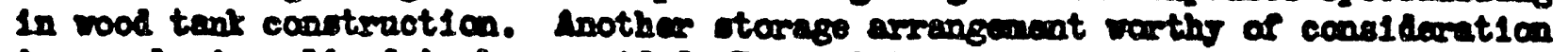

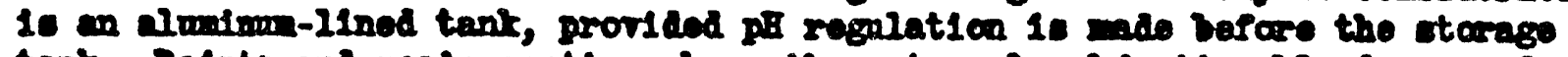

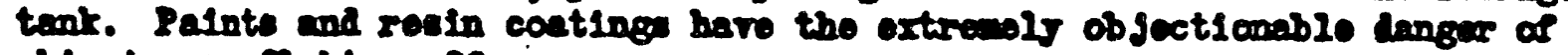
chlpping or rlating orf.

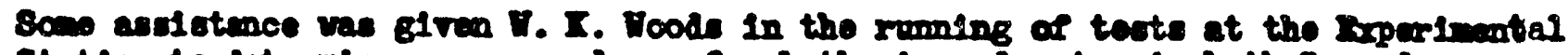
8tation to iotecine prosenre drope for both als and vater in both 3- and 4-ribbed tabing. Fente vere made on trist arille, chip angera, cond oeg and

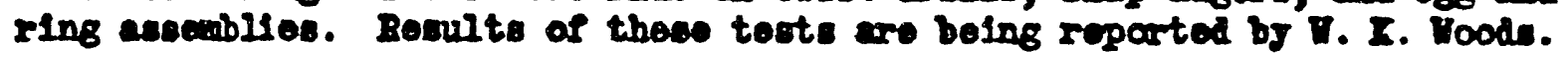

A tud vas ade of calculations of pood for bolling in the p1lo. It is anticipated that som of those data vill have to be recalculated for changos

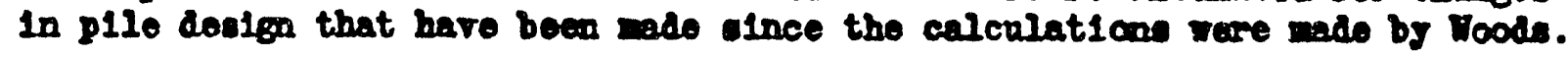

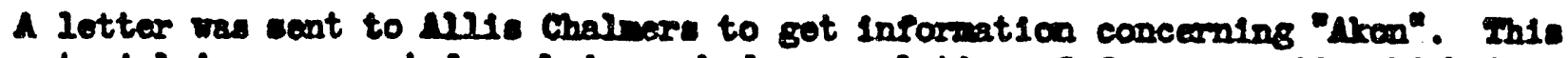

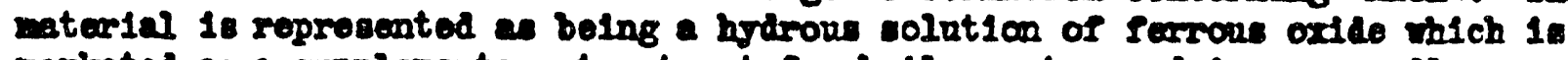
uarkoted as a oupplenentary troatment for boller water and is cupponedis effective in proventing bollar conle, carry-orer, and corrosica. 


\section{P. Ines}

Dotallat conigen and larout of equignont for the experimontal mater treating

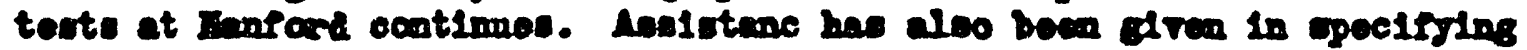
elnilar weter troating oquipment for 81to $X$.

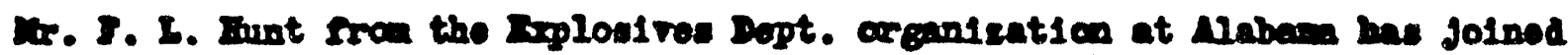
the orom and ofll be located at Banfard to follow the conthruotion of the experincotal rater trating faclifties.

V. I. $\cos \theta$

\section{Inbe Corrosion 8tudr}

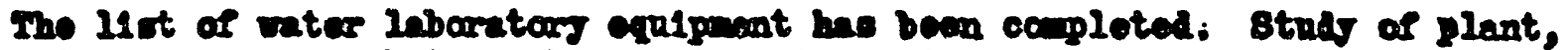

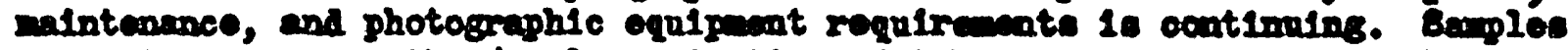

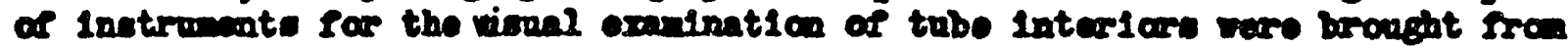

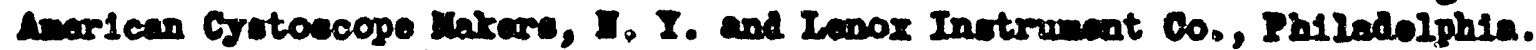

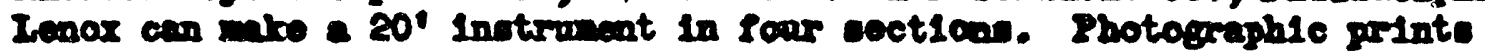

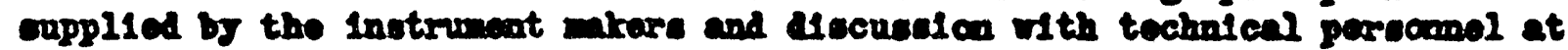
Milton I. IIII, Ine., Indicate that dovelopent of cquipont and techniguse for obtaining veoful photogaraphe of trbe interiare woald probably reguire nore tim then 10 arallablo.

\section{Iollu Pwifleation}

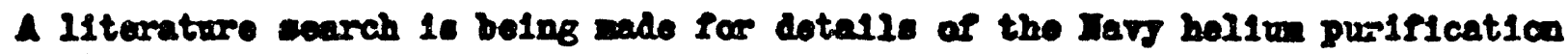
suter.

\section{P. A. Dohlon}

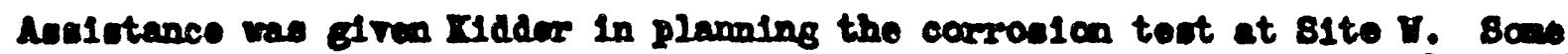
prolininary vark was begun in the proparation of the oporating mamai for thie corronion teat.

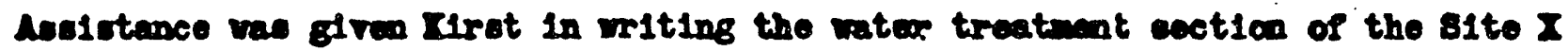
manuel.

$$
200 \text { Area - L. Bquires }
$$

I. Bugree

Tho sotallurgleal Laboratory wa rialted $\mathrm{Mar}$ 18, 19 and 20 to follor the exparimentel evalnetion of the rot Ilnoride and b1 curth phosphate eeparation processes. Curreat otatus of this vork vas revlewed at a notins attended bf Du Ront and Chlcago personnol.

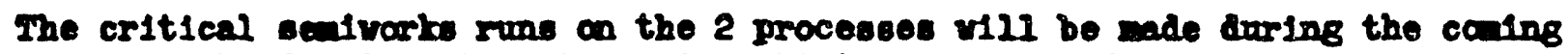
wook and the final mooting to revion all the reoulte of the current progran 18 cehoduled for Jun 1 and 2 at Mbego. Following thl a detalled couparicon

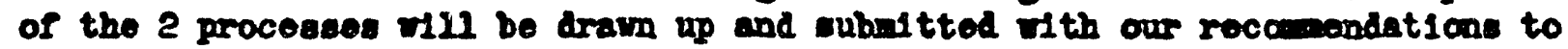
the Banufacturing Divinion in June. 


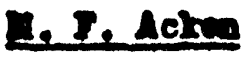

Vecat1on period.

Jamen A. Colling

Tho Initial pbece of an experinontal progran being carrited an at the

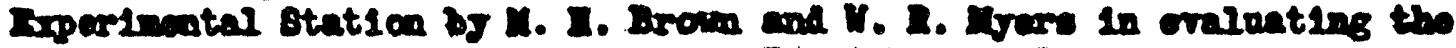

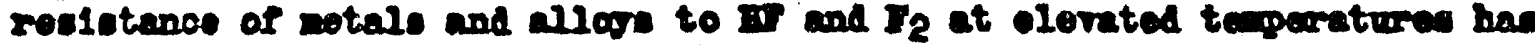

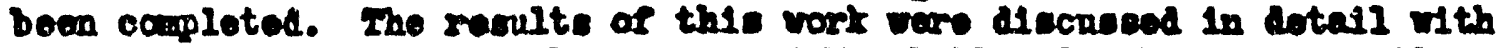

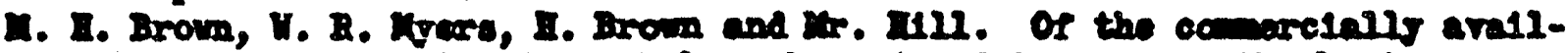

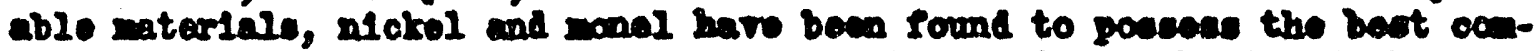

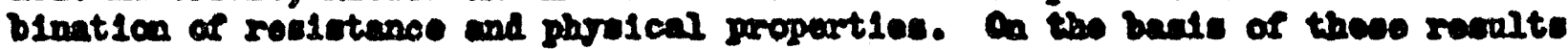

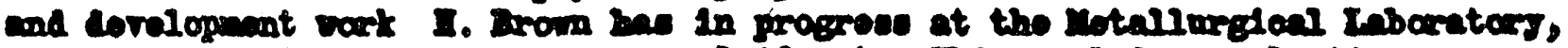

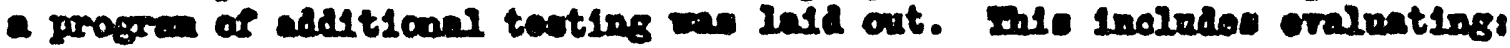

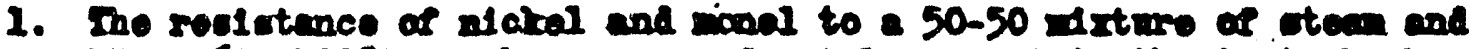

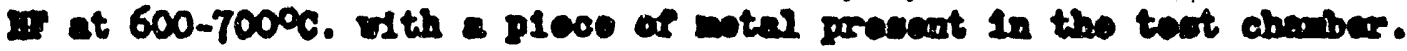

2. The rentetence of nickel and monel in contact rith prodnct eare srom tho wot Inorido cathrectice procose to I2 at 5000, and

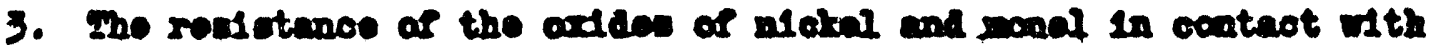
prodnct cake in the blarith phomphnte catrecticn prooses to If at 5000 c.

Tho Metallurgical Laboratary was Nelted on lay 18, 19, and 20. Darlas this time the choulcal groups of O. Beaborg, O. Bar, J. B. Button, and

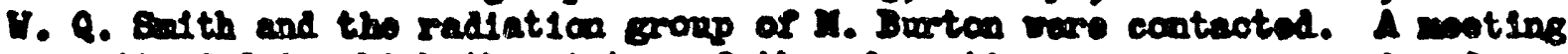
was atteaded in wioh the otatus of the edecrption procens mas rerlewed. daditional text wero roguented by J. Malones on proposed altarnate elnting

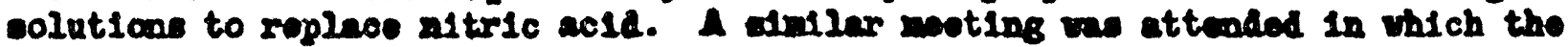

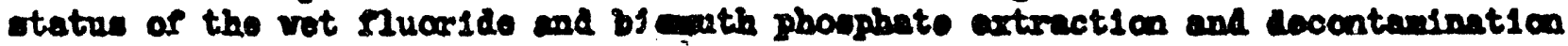

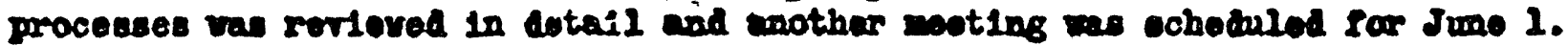

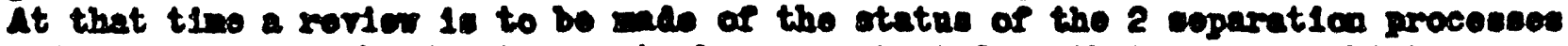

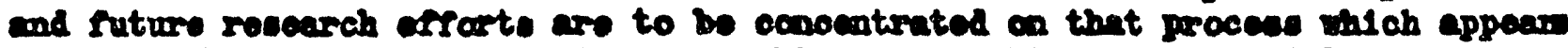

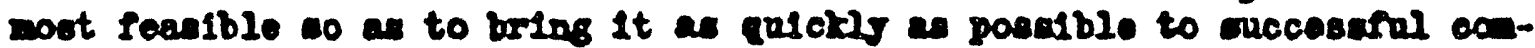
pletion. In importent factor to be considared in reaching this dociolon 10 the relative occrostronese of the 2 procesces and a corroletion of ell corrosica date 18 Doing pepered.

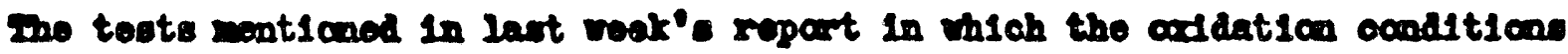

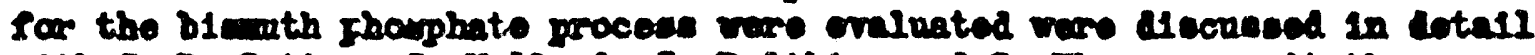
Ith J. B. Button, J. Villard, J. Balthie, and 8. Thopecen. It the provent

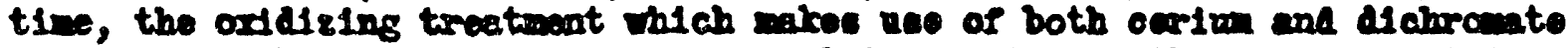

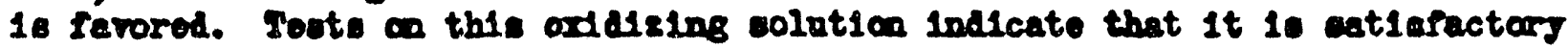
corrosion-rise up to $900 \mathrm{C}$.

In the couplexding of the product cale of the wet nnoweld procese, it vas found that the anount of sirocalun 100 nocessary for ociploto ocplexing reuplted in complicetione in the docontamination oyclo and conalderaticn is being edreo to a partial wotathoelo vith cautic and partial coupleadns of th sirconfun. Io deloterione affecte on corrosion are expected from this nodiflcation. 
Ions 4 . Colling (Gantid)

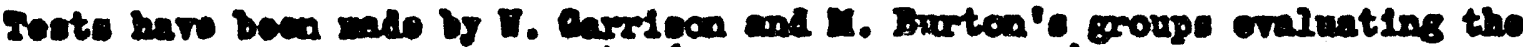

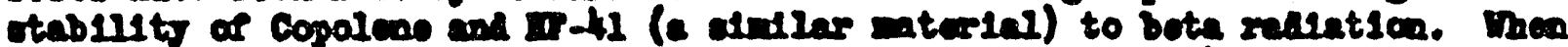

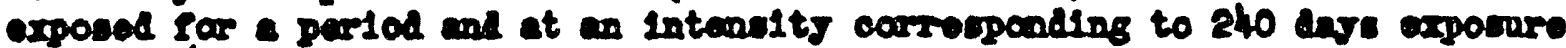

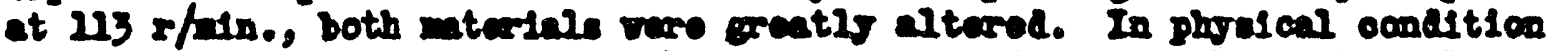

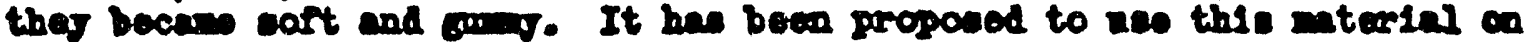

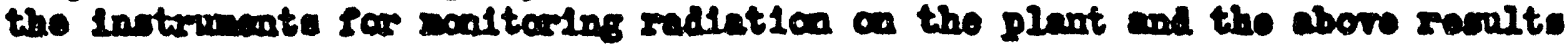

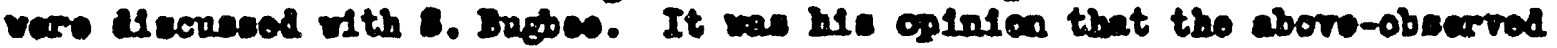
- ffect vould not be encountered ca the Inotronents one to the ponftion of the plak-np charbers in the concrete will around tho operating colls. Culcula-

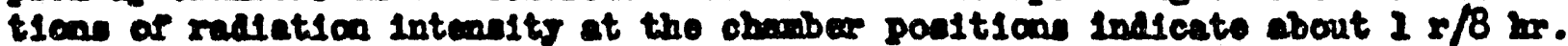

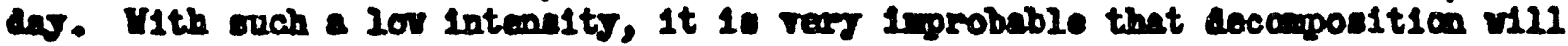
cocur in thow matarials.

\section{8. Croager}

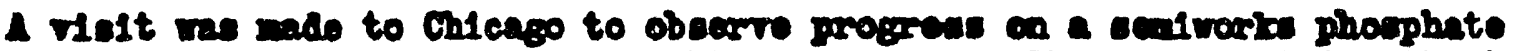

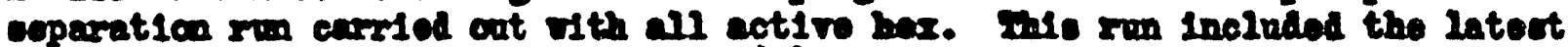

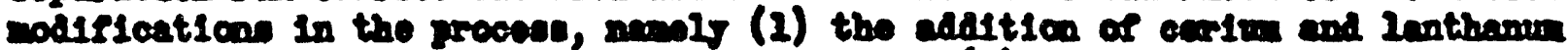

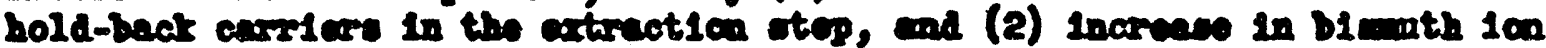

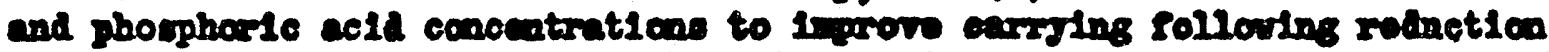
vith parades and ferroes 10a. Decenterination was isprovel over rans of th nixed active and inactive hox, momting to a I0-sold rednoticn in ectivity

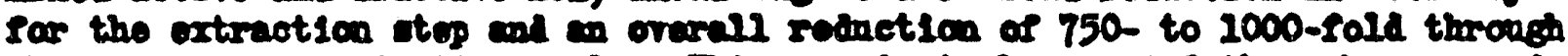

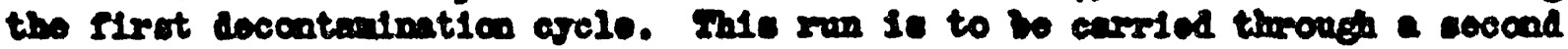
ojcle in the cont-rorbe and a thire ojele in tho laboratory.

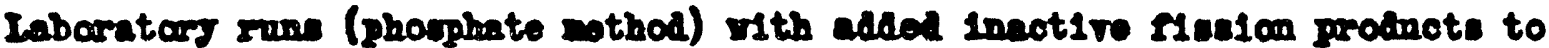

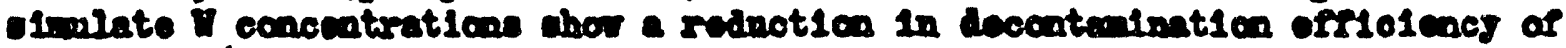

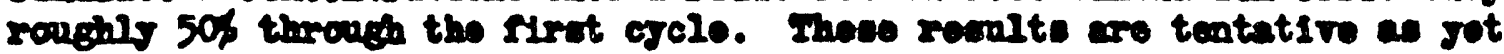

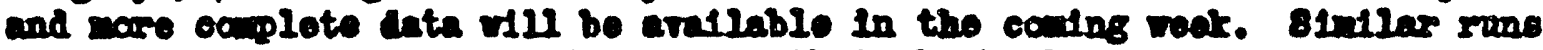

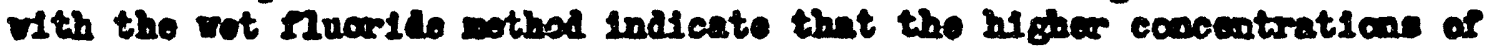

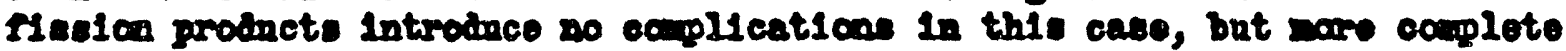
data ere alco to bo obtalod on thile enring the nact roak.

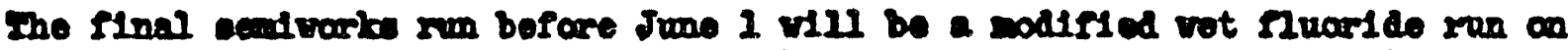
all ective her, and will incorperate changes in catrection and coupling of

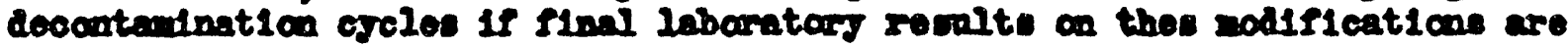
Iavouble.

\section{8. Chmbere}

A moworendun wae propared doseribing the doalen and probablo opariting cycle of the 81te $y$ aleselver.

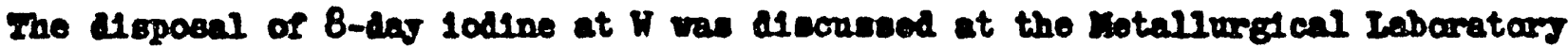
Ith Church, cooper and Ioverett. It ras acreod that the prosent plens for

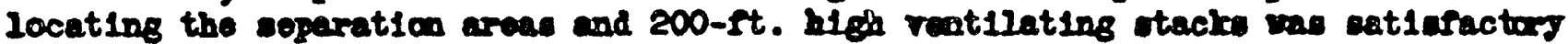
In the light of the noager lata nor avallable. It vas recomendod, hoverer, that sereural alecolvers be provided 10 that a back log of solution could be bullt up on rindy daye. In this mas, it would be possible to alhut cown the

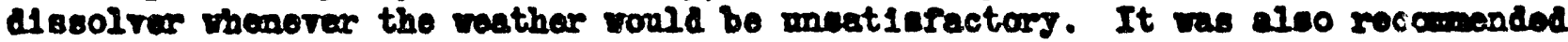




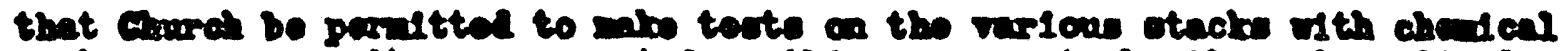

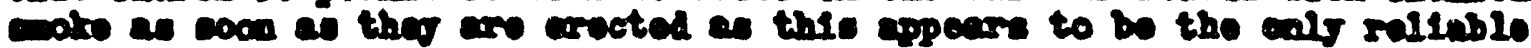

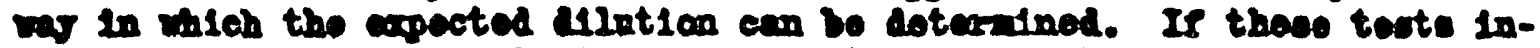

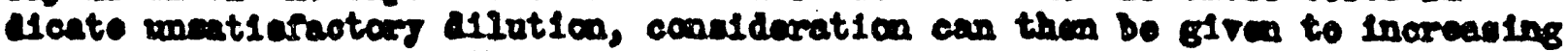
the loces poriod or to the abrorption of the off-eases.

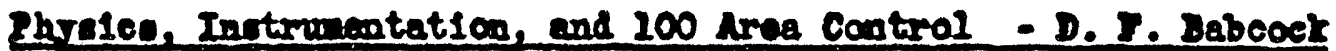

\section{T. Baboook}

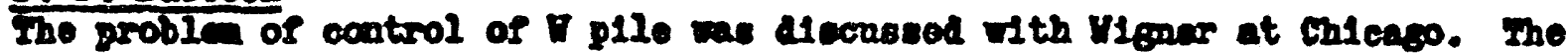
calculation mothode giten by Wheeler for dotwrining tho muber of rode roquired, thelr specing, ete., rece rorlewed and found to be alinilar to those

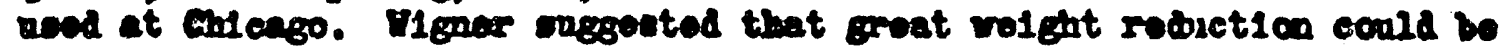
obtalned by viling tho irop cafoty rod in the forn of a crose Instead of a

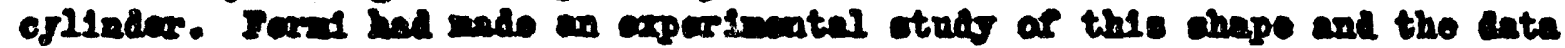

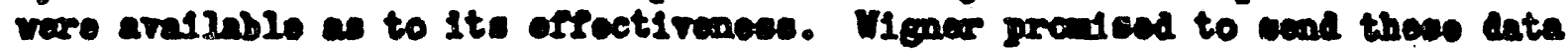
to 20.

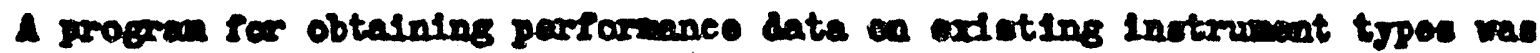

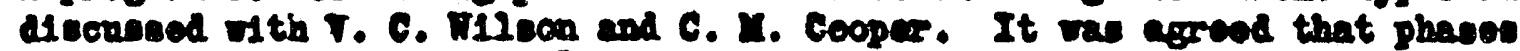

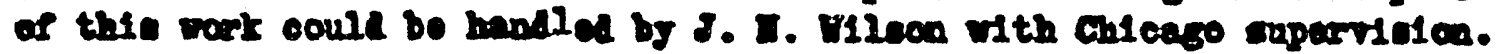

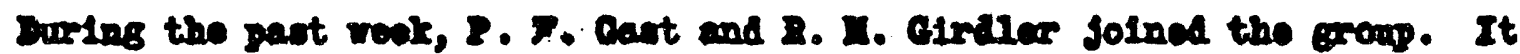

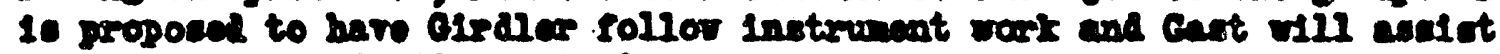
on the problen of pile control.

c. D. I. Inane

Calculation of the ectifitien Indiced in contral rodo, alminn-ocated

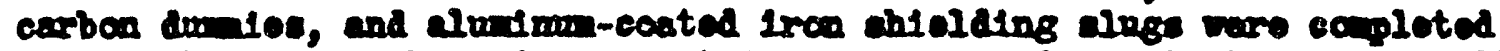
curing the past voak, and a report 10 in proparation. Cantrol rode ofll

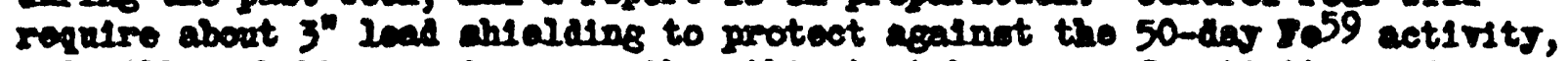
ond ofll probably repulis more then this to tale care of activities of

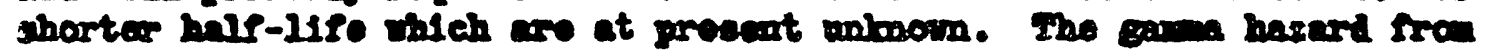

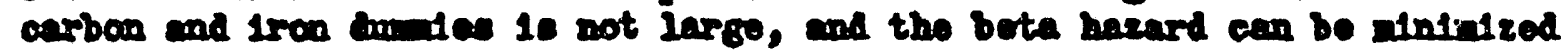
vith littlo elserienlty.

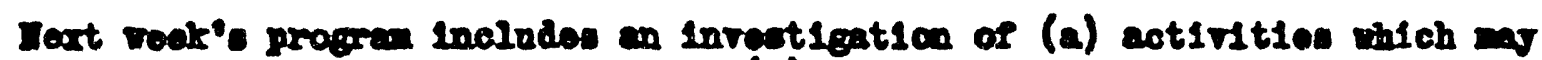

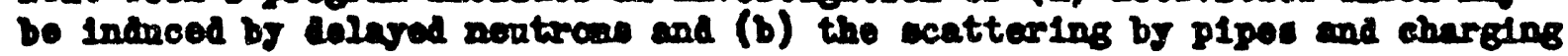

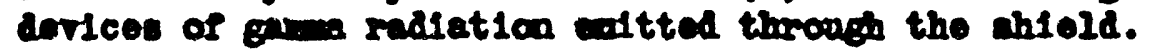

John A. Theoles

Ivalnation of additional mothods of altering the distribution af porrer proluction in a cater cooled plie has boen comploted.

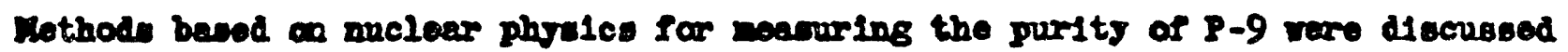

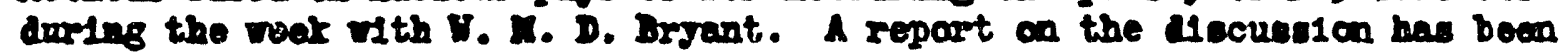
eent to the file.

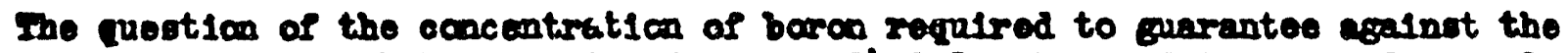
dorelopment of a chalo reaction $\mathrm{rcm}$ the $94-239$ collected in rasto disposal tante is treated in another nemarention. 


\section{Joh A. Doeler (cont'A.)}

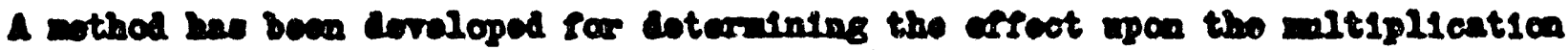
frotor of a lares mober of parallel control rode penotrating a p1le of an ahape in an directica. The efroct of cuddeals puining in or pulling out a control rod on the rete of porrer prodnction of a pile 10 to be furthes inveotignted dering the coning veok.

\section{Eatheren Var}

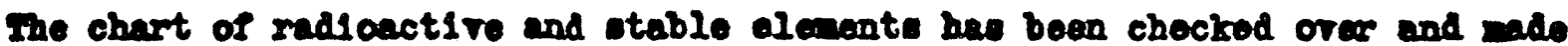

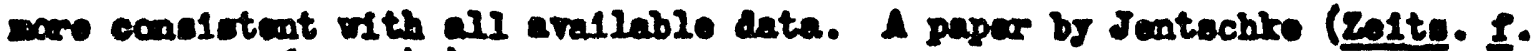
Phre1k 120, 165, 1943) Indicates that there should be som positron activity In tho IIeation producte. A itudy of the chart and the date of the Coryell group at Chloaso Indicates that the 30-das ruthenim and the 60-day 43 an be poritron endtere. These grosses have been passed on to It. Corgell for veriflcation.

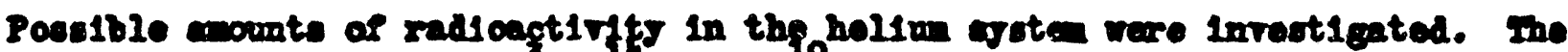

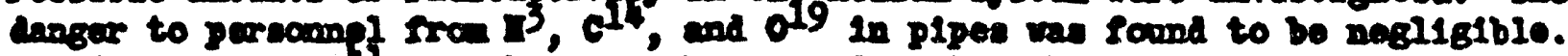

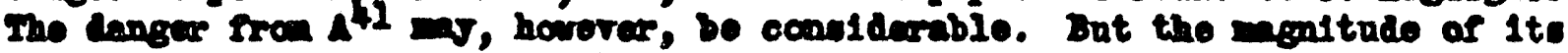

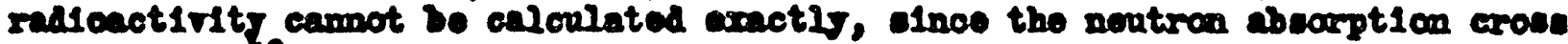
coction of 140 is not boum. Onls an uppar 11nit 10 avaliable at prosent. Ir. Basll at Chlengo uxt1es thet he could neacure this ecose eoction in two reake.

Calculation ware made for Dr. Babcock shoring the rat10 of porrer output at tinos after sho ineartion of control rode to eteady porrer output for 2 s coereace in $\mathbf{k}$.

J. D. Hileon (for poriod onding lar 15 and 22)

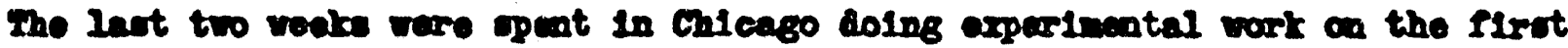

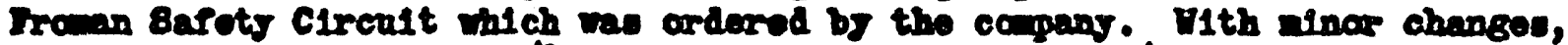

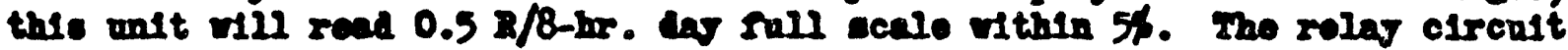

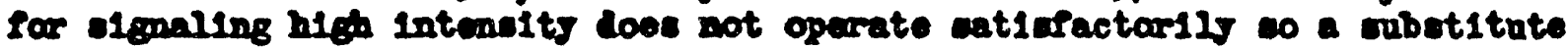
relng hal been ordered.

Mdditican rork is planned at Chicago drected torard obtalning performance data on these inctrunonte.

\section{Clinton - V. I. Iret}

\section{E. E. Erat}

\section{Dater Iubee for $X$}

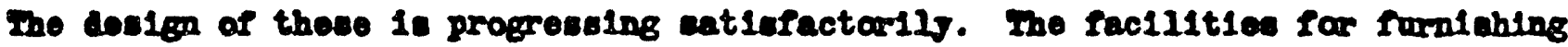
vater of verions degrese of purification for corrosion teste vere discused in

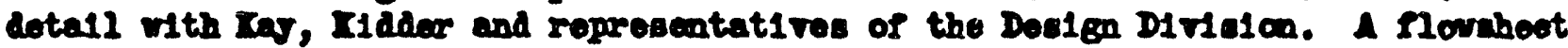
civing the equiphont noedod and the operating charactarietice and ocrice requiro-

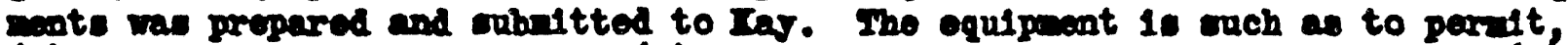
(1) coploto deninoralleation, (2) oxpen and carbon dlordide rewovel, and (3) the controlled addition of osgen, carbon dorddo, oulfurlc ac1d, brdrogen perardde, 
1. I. Irett (cont 'd.)

Calgon and varions other abate.

\section{Blte X Vianal}

\section{Duplication of Individual section has started and malese mporssoen dolare coever, the manal vill be completed in 22 coctions by Jume 15.}

\section{DISCLAIMER}

This report was prepared as an account ci work sponsored by an agency of the United States Government. Neither the United States Jovernment nor any agency thereof, nor any of their employees, makes any warranty, express or implied, or assumes any legal liability or responsibility for the accuracy, completeness, or usefulness of any information, apparatus, product, or process disclosed, or represents that its use would not infringe privately owned rights. Reference herein to any specific commercial product, process, or service by trade name, trademark, manufacturer, or otherwise does not necessarily constitute or imply its endorsement, recommendation, or favoring by the United States Government or any agency thereof. The views and opinions of authors expressed herein do not necessarily state or reflect those of the United States Government or any agency thereof. 

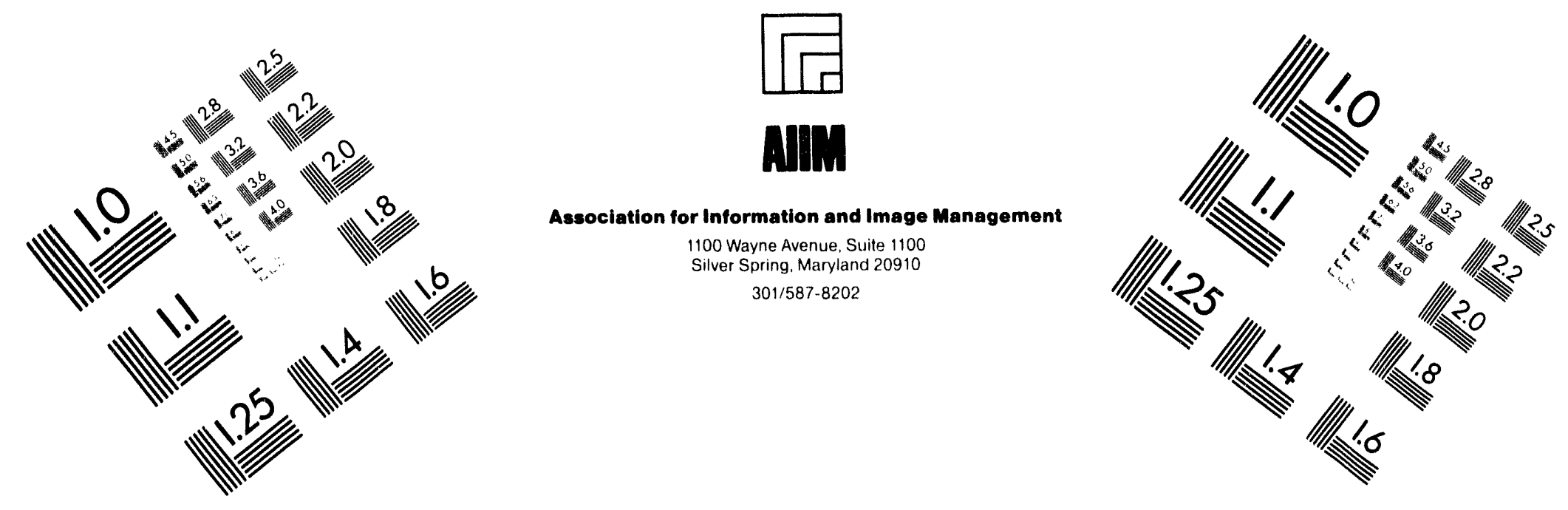

Centimeter

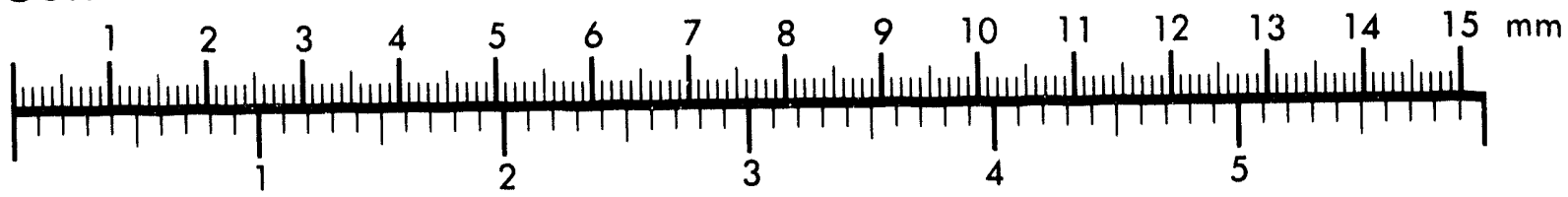

Inches
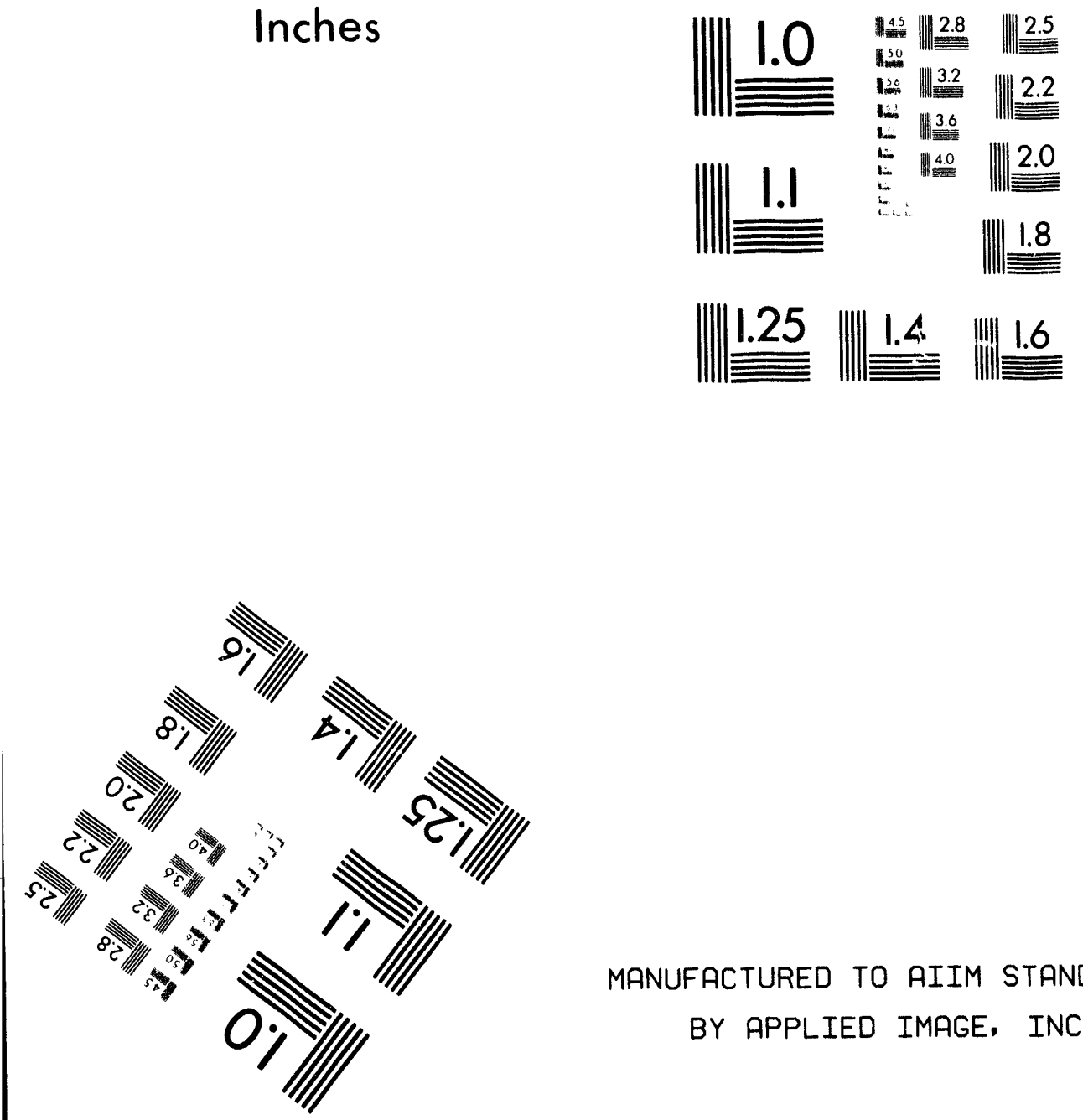

MANUFACTURED TO AIIM STANDARDS

BY APPLIED IMAGE, INC.

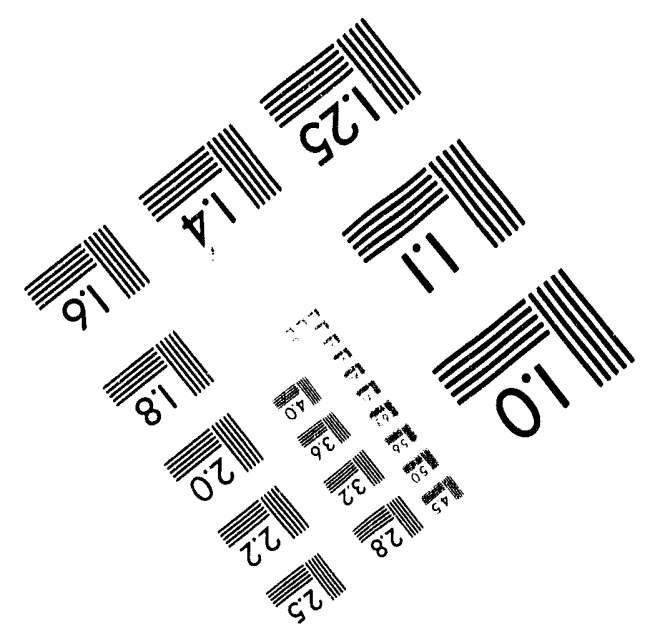




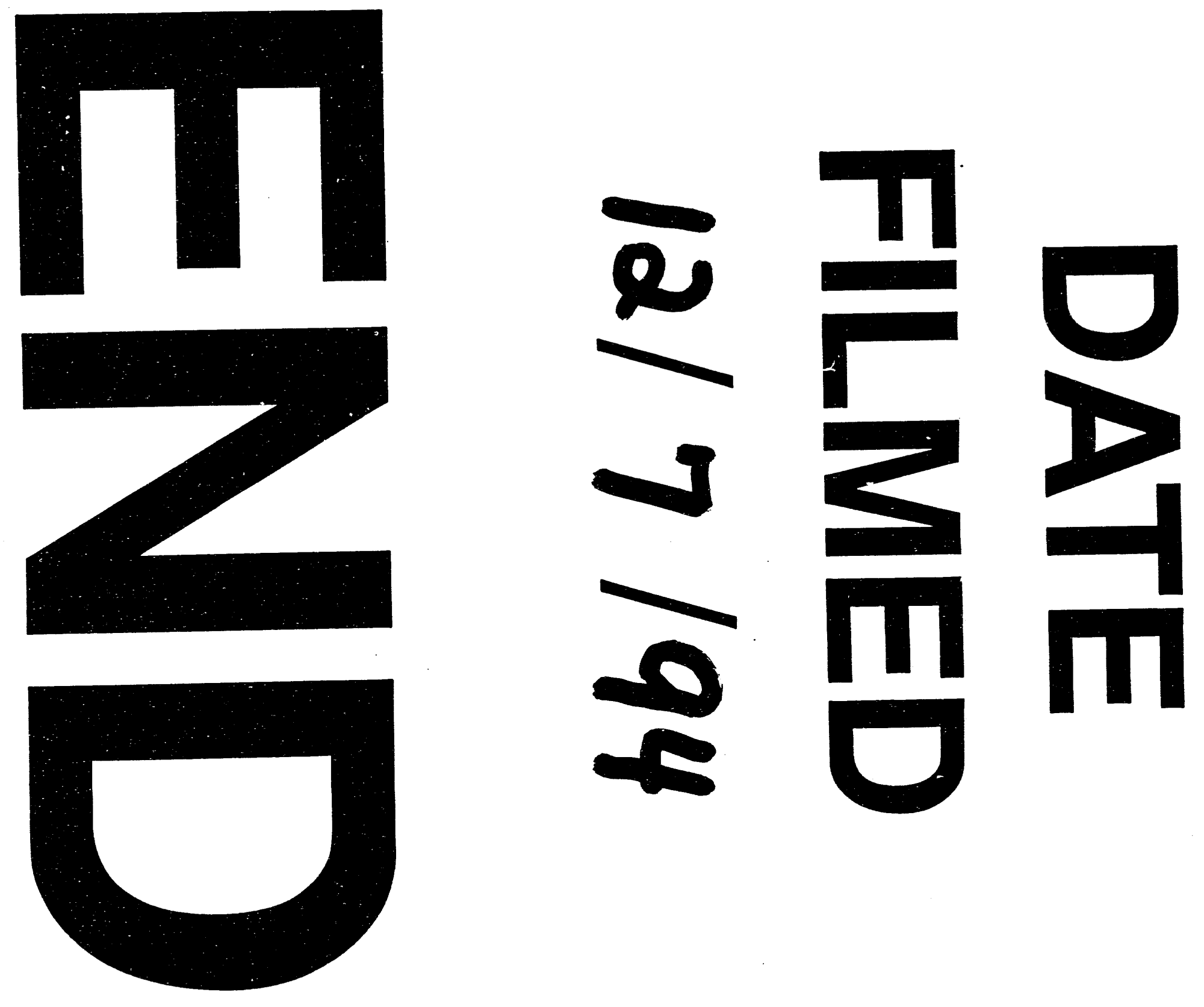